Check for updates

Cite this: RSC Adv., 2019, 9, 32898

Received 27th August 2019

Accepted 27th September 2019

DOI: $10.1039 / c 9 r a 06766 c$

rsc.li/rsc-advances

\section{Cobalt sulfides/carbon nanohybrids: a novel biocatalyst for nonenzymatic glucose biofuel cells and biosensors $\uparrow$}

\begin{abstract}
Zihan Li, ${ }^{a}$ Gangyong Li, ${ }^{a}$ Zhongdong Wu, ${ }^{\text {b }}$ Shuqiang Jiao (iD ${ }^{a}$ and Zongqian Hu (D) *c
Exploring high-performance electrocatalysts is of great importance in developing nonenzymatic biofuel cells. Hybrid nanostructures with transition metal compounds and carbon nanomaterials exhibit excellent electrocatalytic activity and have emerged as promising low-cost alternatives for various electrochemical reactions. Herein, we report cobalt sulfide/carbon nanohybrids via a facile synthesis, which have excellent electrocatalytic activity for glucose oxidation and oxygen reduction reaction. The nonenzymatic glucose biofuel cells equipped with cobalt sulfide/carbon nanohybrids deliver a high open circuit voltage of $0.72 \mathrm{~V}$ with a maximum open power density of $88 \mu \mathrm{W} \mathrm{cm}{ }^{-2}$, indicating that cobalt sulfide/carbon nanohybrids are high performance biocatalysts for bioenergy conversion.
\end{abstract}

\section{Introduction}

Enzymatic glucose biofuel cells are a special type of fuel cell that convert energetic biomass into electric energy through bioelectrochemical pathways using a bio-enzyme as a catalyst. ${ }^{1-5}$ During the anode reaction, glucose oxidase or glucose dehydrogenase is usually used for the oxidation of glucose, ${ }^{6}$ while laccase or bilirubin oxidase is adopted as the cathodic catalyst for the oxygen reduction reaction (ORR). ${ }^{4,7}$ In the past decade, a few glucose biofuel cells have been successfully implanted in organisms such as oranges, ${ }^{8}$ clams, ${ }^{9}$ snails ${ }^{10}$ and rats. ${ }^{11,12}$ However, the practical applications of glucose biofuel cells are limited due to the poor stability, ${ }^{13}$ rough immobilization technology ${ }^{\mathbf{1 4}}$ and susceptibility to the operating environment of the enzymes. ${ }^{15}$

To overcome the drawbacks of the enzyme, some metal-based nanomaterials (e.g. precious metals, ${ }^{13,16}$ metal complexes ${ }^{17}$ ) have been used as the catalysts to replace the bio-enzyme to fabricate nonenzymatic glucose biofuel cells (NGBCs). However, most of the NGBCs use precious metals as cathodic or anodic catalysts. ${ }^{13,16,18}$ Although the high cost and scarcity of these precious metals severely limit their applications. ${ }^{\mathbf{1 9 , 2 0}}$ In this regard, developing non-precious metal anodes and cathodes in NGBCs is highly challenging but imperative for practical applications. Currently, transition metals and their composites have received

${ }^{a}$ State Key Laboratory of Advanced Metallurgy, University of Science and Technology Beijing, Beijing, 100083, P. R. China

${ }^{b}$ College of Materials Science and Engineering, Central South University of Forestry and Technology, Changsha, 410004, P. R. China

${ }^{c}$ Beijing Institute of Radiation Medicine, Beijing, 100850, P. R. China. E-mail: huzongqian@hotmail.com; Tel: +86-10-66932251

$\dagger$ Electronic supplementary information (ESI) available. See DOI: 10.1039/c9ra06766c wide attention, especially cobalt, due to its good biocompatibility, low cost and higher natural abundance compared with precious metals. ${ }^{21-23}$ Cobalt has been widely used as catalysts because of its loosely bound d electrons. ${ }^{24}$ While cobalt sulfides have been investigated as overall water splitting ${ }^{25}$ and carbon dioxide $\left(\mathrm{CO}_{2}\right)$ reduction ${ }^{24}$ catalysts due to their excellent electrochemical activity among different transition metal chalcogenides. ${ }^{26-30}$ However, cobalt sulfides have still been seldomly reported as the dual electrode electrocatalysts of NGBCs. In addition, cobalt sulfides have low charge transport because of their poor electronic conductivity. ${ }^{25}$ Thus, integrating cobalt sulfides with conducting carbon nanomaterials is an important strategy to increase their electroactive area and enhance the electronic conductivity. ${ }^{31-33}$

In this work, we report a novel NGBC based on cobalt sulfides as dual electrode electrocatalysts. In the anode section, we designed a non-precious metal anode catalyst $\left(\mathrm{Co}_{3} \mathrm{~S}_{4}\right.$ and graphene hybrid, $\left.\mathrm{Co}_{3} \mathrm{~S}_{4}-\mathrm{G}\right)$ via a simple controlled method. The $\mathrm{Co}_{3} \mathrm{~S}_{4}-\mathrm{G}$ sample showed an excellent glucose oxidation activity, high sensitivity $\left(687.13 \mu \mathrm{A} \mathrm{cm}{ }^{-2} \mathrm{mM}^{-1}\right)$, low detection limit $(0.4$ $\mu \mathrm{M}$ ), fast response and good selectivity toward the detection of glucose. Alternatively, we used cobalt sulfide and a carbon nanotube hybrid $\left(\mathrm{Co}_{1-x} \mathrm{~S}-\mathrm{CNT}\right)$ as the cathode catalyst. The $\mathrm{Co}_{1-x} \mathrm{~S}-$ CNT performed at an onset potential of $0.01 \mathrm{~V}(\mathrm{vs}$. $\mathrm{Hg} / \mathrm{HgO})$, which was close to that of commercial Pt/C $(0.025 \mathrm{~V})$ and a positive shift $(20 \mathrm{mV})$ in the half wave potentials compared to commercial Pt/C. As a result, an enhanced NGBC was achieved on the basis of high glucose oxidation and oxygen reduction performance.

\section{Experimental}

\subsection{Material synthesis}

2.1.1. Synthesis of graphene oxide (GO). GO was made according to our previous report with modifications. ${ }^{3}$ One gram of 
graphite flakes (99.8\%, Alfa Aesar) and $1 \mathrm{~g}$ of sodium nitrate $\left(\mathrm{NaNO}_{3}, 99 \%\right.$, Sinopharm Chemical Reagent Co., Ltd) were mixed with $50 \mathrm{~mL}$ concentrated $\mathrm{H}_{2} \mathrm{SO}_{4}$ in a $250 \mathrm{~mL}$ round-bottom flask with an ice-water bath. After stirring for $30 \mathrm{~min}, 6 \mathrm{~g}$ of $\mathrm{KMnO}_{4}$ was slowly added into the mixture and stirred for $6 \mathrm{~h}$ at $40{ }^{\circ} \mathrm{C}$. Then, $100 \mathrm{~mL}$ of deionized water was slowly added into the mixture and gently stirred for $30 \mathrm{~min}$ at $90^{\circ} \mathrm{C}$. Afterward, $\mathrm{H}_{2} \mathrm{O}_{2}$ aqueous solution (30\%, Sinopharm Chemical Reagent Co., Ltd) was added dropwise into the mixture until the color turned bright yellow. Finally, the mixture was centrifuged and washed thoroughly with $1 \mathrm{M} \mathrm{HCl}$ and deionized water. The as-prepared GO was freeze-dried.

2.1.2. Synthesis of the $\mathrm{Co}_{3} \mathrm{~S}_{4}$ and graphene hybrid $\left(\mathrm{Co}_{3} \mathrm{~S}_{4}-\right.$ G). $100 \mathrm{mg}$ of GO was dispersed in $40 \mathrm{~mL}$ deionized water. Then $1.454 \mathrm{~g}$ of cobalt nitrate hexahydrate $\left(\mathrm{Co}\left(\mathrm{NO}_{3}\right) \cdot 6 \mathrm{H}_{2} \mathrm{O}, 98.5 \%\right.$, Sinopharm Chemical Reagent Co., Ltd) was added into the GO aqueous solution and stirred for $20 \mathrm{~min}$. 2-Methylimidazole (2mlm, 99\%, Sinopharm Chemical Reagent Co., Ltd) was dispersed in another $60 \mathrm{~mL}$ deionized water and, after it completely dissolved, it was quickly added to the above mentioned mixture, and stirred for $30 \mathrm{~min}$. The composite of Co-MOF and GO (denoted as Co-MOF-GO) was obtained after centrifugation and dried overnight at $60{ }^{\circ} \mathrm{C}$. Then, Co-MOF-GO was mixed with sublimed sulfur (S, 99.5\%, Sinopharm Chemical Reagent Co., Ltd) at a mass ratio of $1: 3$, then heated in a furnace filled with argon at $800{ }^{\circ} \mathrm{C}$ for $2 \mathrm{~h}$ (heating rate $5{ }^{\circ} \mathrm{C} \mathrm{min}^{-1}$ ) to obtain the $\mathrm{Co}_{1-x} \mathrm{~S} /$ $\mathrm{Co}_{9} \mathrm{~S}_{8}$ and graphene hybrid (denoted as $\mathrm{Co}_{1-x} \mathrm{~S} / \mathrm{Co}_{9} \mathrm{~S}_{8}-\mathrm{G}$ ). Finally, the $\mathrm{Co}_{1-x} \mathrm{~S} / \mathrm{Co}_{9} \mathrm{~S}_{8}-\mathrm{G}$ powder was annealed in a muffle furnace at $300{ }^{\circ} \mathrm{C}$ for $3 \mathrm{~h}$ (heating rate $2{ }^{\circ} \mathrm{C} \mathrm{min}{ }^{-1}$ ) to obtain $\mathrm{Co}_{3} \mathrm{~S}_{4}-\mathrm{G}$.

2.1.3. Synthesis of the $\mathrm{Co}_{1-x} \mathrm{~S}$ and carbon nanotube hybrid (Co ${ }_{1-x}$ S-CNT). $50 \mathrm{mg}$ of carbon nanotube (CNT) and $300 \mathrm{mg}$ of poly(vinylpolypyrrolidone) (PVP, K29-32, Sinopharm Chemical Reagent Co., Ltd) were dispersed in $50 \mathrm{~mL}$ methanol. $1.454 \mathrm{~g}$ of $\mathrm{Co}\left(\mathrm{NO}_{3}\right) \cdot 6 \mathrm{H}_{2} \mathrm{O}$ and $3.28 \mathrm{~g}$ 2-mlm were both dissolved in $25 \mathrm{~mL}$ methanol. First, the solution of $\mathrm{Co}\left(\mathrm{NO}_{3}\right) \cdot 6 \mathrm{H}_{2} \mathrm{O}$ was added into the solution of the CNT, and stirred for $20 \mathrm{~min}$. And then, added the solution of $2-\mathrm{mlm}$, stirring for $2 \mathrm{~h}$ at room temperature. This was followed by centrifugation to obtain the composite of CoMOF and CNT (denoted as Co-MOF-CNT). Then, Co-MOFCNT was mixed with sublimed sulfur at a mass ratio of $1: 3$, and heated in a furnace filled with argon at $800{ }^{\circ} \mathrm{C}$ for $2 \mathrm{~h}$ (heating rate $5{ }^{\circ} \mathrm{C} \min ^{-1}$ ) to obtain $\mathrm{Co}_{1-x} \mathrm{~S}-\mathrm{CNT}$.

\subsection{Characterization}

X-ray diffraction (XRD) measurements were performed by a PANalytical X'pert Pro X-ray diffractometer using $\mathrm{Cu} \mathrm{K} \alpha$ radiation $(\lambda=1.5418 \AA$ ). Raman spectra were obtained using a WITecCRM200 instrument with a $532 \mathrm{~nm}$ laser. X-ray photoelectron spectroscopy (XPS) analysis was recorded on a Thermo Scientific Escalab 250 spectrometer by using an $\mathrm{Al} \mathrm{K \alpha} \mathrm{X}$-ray source. The morphologies were characterized by a field emission scanning electron microscopy (FESEM, JSM-6701) and transmission electron microscopy (TEM, JEOL JEM-2100).

\subsection{Electrochemical tests}

2.3.1. Glucose oxidation reaction (GOR) test. Typically, $5 \mu \mathrm{L}$ of $5 \mathrm{mg} \mathrm{mL}{ }^{-1} \mathrm{Co}_{3} \mathrm{~S}_{4}-\mathrm{G}$ suspension (dispersed in deionized water and DMF at a volume ratio of $1: 1)$ was cast on the surface of the pretreated glass carbon electrode (GCE, $3 \mathrm{~mm}$ in diameter) and dried in air (denoted as $\mathrm{Co}_{3} \mathrm{~S}_{4}-\mathrm{G} / \mathrm{GCE}$ ). All the electrochemical measurements were carried out on a CHI $660 \mathrm{E}$ electrochemical analyzer (Shanghai, China) using a three-electrode system configuration with a $0.1 \mathrm{M} \mathrm{KOH}$ solution as the electrolyte, in which the above mentioned modified glass carbon was used as the working electrode, Pt foil (surface area: $1 \mathrm{~cm}^{2}$ ) as the counter electrode and a $\mathrm{Hg} / \mathrm{HgO}$ electrode as the reference electrode. Meanwhile, the solutions were deoxygenated with highly pure argon $(99.99 \%)$ for at least $15 \mathrm{~min}$ before tests.

2.3.2. Oxygen reduction reaction (ORR) test. The electrochemical performance was recorded on a $\mathrm{CHI} 760 \mathrm{E}$ electrochemical workstation with a typical three-electrode cell. A Hg/ $\mathrm{HgO}$ electrode full of $1 \mathrm{M} \mathrm{KOH}$ aqueous solution was used as the reference electrode, and a Pt wire was utilized as the counter electrode. $5 \mathrm{mg}$ of the sample $\left(\mathrm{Co}_{1-x} \mathrm{~S}-\mathrm{CNT}\right)$ and $16 \mu \mathrm{L}$ of $5 \mathrm{wt} \%$ Nafion solution were dispersed into $1 \mathrm{~mL}$ of $3: 1 \mathrm{v} / \mathrm{v}$ water/ isopropanol mixed solution and then ultrasonicated for an hour to get a homogeneous suspension. $4 \mu \mathrm{L}$ of this suspension (0.1 $\mathrm{mg} \mathrm{cm}^{-2}$ ) were dropped on a pre-treated glassy carbon rotating disk electrode ( $5 \mathrm{~mm}$ in diameter) and dried in air for use as the working electrode. The ORR activity was detected in $\mathrm{O}_{2}$-saturated $0.1 \mathrm{M} \mathrm{KOH}$ solution by using a rotating disk electrode (Pine Instruments). The linear sweep voltammograms (LSV) were recorded under a rotating speed of $1600 \mathrm{rpm}$ at a scan rate of $5 \mathrm{mV} \mathrm{s}^{-1}$.

For the rotating ring-disk electrode (RRDE) measurements, a rotating ring disk electrode with a glassy carbon disk and a Pt ring (Pine Instruments) was used as the working electrode. The disk electrode was scanned cathodically at a rate of $5 \mathrm{mV} \mathrm{s}^{-1}$ and the ring electrode's potential was constant at $1.5 \mathrm{~V} v s$. RHE. The electron transfer number and $\% \mathrm{HO}_{2}{ }^{-}$were determined by the equations:

$$
\begin{gathered}
n=4 \times \frac{\mathrm{i} d}{\mathrm{i} d+\mathrm{i} r / N} \\
\% \mathrm{HO}_{2}^{-}=200 \times \frac{\mathrm{i} r / N}{\mathrm{i} d+\mathrm{i} r / N}
\end{gathered}
$$

where $\mathrm{i} d$ is disk current, ir is ring current and $N$ is current collection efficiency of the $\mathrm{Pt}$ ring, $N$ was 0.37 from the instruction manual.

2.3.3. Full cell test. The full cell, made in house with an " $\mathrm{H}$ " type electrolytic pool, was separated by a Nafion 117 membrane. Ar-saturated 0.1 M glucose/0.1 M KOH solution was used as an anolyte in the anode chamber, and $\mathrm{O}_{2}$-saturated $0.04 \mathrm{M} \mathrm{B}-\mathrm{R}(\mathrm{pH}$ 5.0) solution was used as a catholyte in the cathode chamber. The $\mathrm{Co}_{3} \mathrm{~S}_{4}-\mathrm{G} / \mathrm{GCE}$ was used as the anode electrode. $10 \mathrm{mg}$ of $\mathrm{Co}_{1-x} \mathrm{~S}-\mathrm{CNT}$ or $\mathrm{Pt} / \mathrm{C}$ (10\%, Sigma Aldrich) was dispersed into $1 \mathrm{~mL}$ deionized water with adding $50 \mu \mathrm{L}$ Nafion solution ( $5 \mathrm{wt} \%$ ) and then ultrasonicated for an hour to get a homogeneous suspension. $200 \mu \mathrm{L}$ of this suspension was loaded on a pretreated carbon paper $\left(2 \mathrm{~cm}^{-2}\right)$ and dried in air for use as the cathode electrode. The power output of the full cell was recorded on a CHI 660E electrochemical workstation using LSV at a scan rate of $1 \mathrm{mV} \mathrm{s}^{-1}$. 


\section{Results and discussion}

The X-ray diffraction (XRD) patterns of the $\mathrm{Co}_{1-x} \mathrm{~S} / \mathrm{Co}_{9} \mathrm{~S}_{8}-\mathrm{G}$ and $\mathrm{Co}_{3} \mathrm{~S}_{4}-\mathrm{G}$ hybrid are shown in Fig. 1a. For the $\mathrm{Co}_{1-x} \mathrm{~S} / \mathrm{Co}_{9} \mathrm{~S}_{8}-\mathrm{G}$ hybrid, different diffraction peaks at $2 \theta=30.5^{\circ}, 35.1^{\circ}, 46.7^{\circ}$, $54.2^{\circ}$ corresponding to the (100), (101), (102), (110) plane reflections of $\mathrm{Co}_{1-x} \mathrm{~S}$ (PDF\#42-0826) and different diffraction peaks at $2 \theta=29.9^{\circ}, 47.7^{\circ}, 52.2^{\circ}$, corresponding to the (311), (511), (440) plane reflection of $\mathrm{Co}_{9} \mathrm{~S}_{8}$ (PDF\#75-2023) were present. The $\mathrm{Co}_{1-x} \mathrm{~S} / \mathrm{Co}_{9} \mathrm{~S}_{8}-\mathrm{G}, \mathrm{Co}_{3} \mathrm{~S}_{4}-\mathrm{G}$ hybrid showed different diffraction peaks at $2 \theta=26.8^{\circ}, 31.5^{\circ}, 38.2^{\circ}, 50.4^{\circ}, 55.2^{\circ}$, corresponding to the (220), (311), (400), (511), (440) plane reflections of $\mathrm{Co}_{3} \mathrm{~S}_{4}$ (PDF\#74-0138), respectively. However, from the XRD patterns, it was observed that some impurity exists, indicating that there is possibly a small quantity of $\mathrm{Co}_{3} \mathrm{O}_{4}$ doped in the $\mathrm{Co}_{3} \mathrm{~S}_{4}-\mathrm{G}$ hybrid.

In order to confirm the chemical composition and valence of $\mathrm{Co}_{3} \mathrm{~S}_{4}-\mathrm{G}$, the electronic states of the Co and $\mathrm{S}$ phases were identified by X-ray photoelectron spectroscopy (XPS) measurements. Fig. $1 \mathrm{~b}$ shows the XPS spectrum of $\mathrm{Co}_{3} \mathrm{~S}_{4}-\mathrm{G}$. The Co $2 \mathrm{p}$ core-level spectra showed two predominant peaks (Co $2 \mathrm{p}_{3 / 2}$ and Co $2 \mathrm{p}_{1 / 2}$ ) with an energy separation of about $15.4 \mathrm{eV}$, as shown in Fig. 1c, indicating the presence of $\mathrm{Co}_{3} \mathrm{~S}_{4}{ }^{34}$ The high resolution of the $\mathrm{S} 2 \mathrm{p}$ spectrum (Fig. 1d) displayed peaks located at 163.7, 164.8 and $165.4 \mathrm{eV}$, which correspond to the $\mathrm{S} 2 \mathrm{p}_{3 / 2}, \mathrm{~S} 2 \mathrm{p}_{1 / 2}$ and $\mathrm{S}-\mathrm{C}$ respectively. The peak at $168.8 \mathrm{eV}$ identifies the presence of $\mathrm{S}-\mathrm{O}$ binding, suggesting a partial oxidation of the $\mathrm{Co}_{3} \mathrm{~S}_{4}$ shell on the surface. ${ }^{35}$ Fig. S1a $\uparrow$ shows that the $\mathrm{O} 1 \mathrm{~s}$ spectrum was comprised of three components: oxygen atoms in the hydroxyl group, absorbed water, and O-Co bonds. ${ }^{36}$ The $\mathrm{N} 1 \mathrm{~s}$ and $\mathrm{C} 1 \mathrm{~s}$ spectrum of $\mathrm{Co}_{3} \mathrm{~S}_{4}-\mathrm{G}$ are displayed in Fig. S1. $\dagger$

Morphological and structural characterizations of the $\mathrm{Co}_{3} \mathrm{~S}_{4}-\mathrm{G}$ hybrid and its precursors were investigated by SEM and TEM. The SEM (Fig. 2a and b) and TEM (Fig. 2c) images clearly show the formation of $\mathrm{Co}_{3} \mathrm{~S}_{4}$ particles with an average size of $\sim 40 \mathrm{~nm}$ on graphene sheets. The graphene sheets can not only induce higher porosity to facilitate ion diffusion but also inhibit the aggregation of the composites. As shown in Fig. 2d, the ordered lattice interplanar spacings were around $0.176 \mathrm{~nm}$ from a high-resolution TEM image of the (311) plane of $\mathrm{Co}_{3} \mathrm{~S}_{4}$.

The phase composition and morphology of the $\mathrm{Co}_{1-x} \mathrm{~S}-\mathrm{CNT}$ hybrid were characterized by the same method. XRD analyses are shown in Fig. 1e, and the sharp diffraction peaks from hexagonal $\mathrm{Co}_{1-x} \mathrm{~S}$ (PDF\#42-0826) appear obviously, with different peaks at $2 \theta=30.5^{\circ}, 35.2^{\circ}, 46.7^{\circ}, 54.2^{\circ}$ corresponding to the (100), (101), (102), (110) plane reflections of $\mathrm{Co}_{1-x} \mathrm{~S}$, respectively. XPS was used to further analyze the chemical composition and valence of the $\mathrm{Co}_{1-x} \mathrm{~S}-\mathrm{CNT}$ hybrid. As shown in Fig. $1 \mathrm{~g}$, the Co $2 \mathrm{p}_{1 / 2}$ and Co $2 \mathrm{p}_{3 / 2}$ spin-orbit coupling accompanied with weak satellite peaks can be deconvoluted from the Co $2 \mathrm{p}$ spectrum. The peaks located at $778.3 \mathrm{eV}$ and $793.4 \mathrm{eV}, 780.6 \mathrm{eV}$ and $796.4 \mathrm{eV}$ indicate the presence of $\mathrm{Co}^{3+}$ and $\mathrm{Co}^{2+}$, respectively. ${ }^{37}$ The $\mathrm{S} 2 \mathrm{p}$ spectrum was deconvoluted into $\mathrm{S} 2 \mathrm{p} 1 / 2$ and $\mathrm{S} \mathrm{2p} 3 / 2$ of $\mathrm{S}^{2-}$ in $\mathrm{Co}_{1-x} \mathrm{~S}$ at $161.7 \mathrm{eV}$ and $163 \mathrm{eV}$ as shown in Fig. $1 \mathrm{~h}$, and another peak at $168.6 \mathrm{eV}$ corresponded to the oxidized S, possibly caused by oxidation in the air. ${ }^{38}$ The C 1s spectrum is shown in Fig. S2. $\dagger$

Morphological and structural characterizations of the $\mathrm{Co}_{1-x} \mathrm{~S}-\mathrm{CNT}$ hybrid was investigated by SEM and TEM. As shown in Fig. 2e and f, irregular polygon $\mathrm{Co}_{1-x} \mathrm{~S}$ particles were anchored on the surface of CNTs. The CNTs provide highly conductive pathways for electron transfer between the electrode material and the current collector to improve the overall electrical conductivity. ${ }^{39}$ The TEM images shown in Fig. $2 \mathrm{~g}$ confirm the close relationship between the $\mathrm{Co}_{1-x} \mathrm{~S}$ particles and CNTs, which is consistent with SEM characterization. The high-resolution TEM image is shown in Fig. $2 \mathrm{~h}$, where the crystal lattice fringe with an inter-planar distance of $0.196 \mathrm{~nm}$ matches well with the dominant XRD peak (101) of $\mathrm{Co}_{1-x} \mathrm{~S}$. All the characterizations above indicate that the $\mathrm{Co}_{3} \mathrm{~S}_{4}-\mathrm{G}$ and $\mathrm{Co}_{1-x} \mathrm{~S}-\mathrm{CNT}$ hybrids were successfully synthesized.
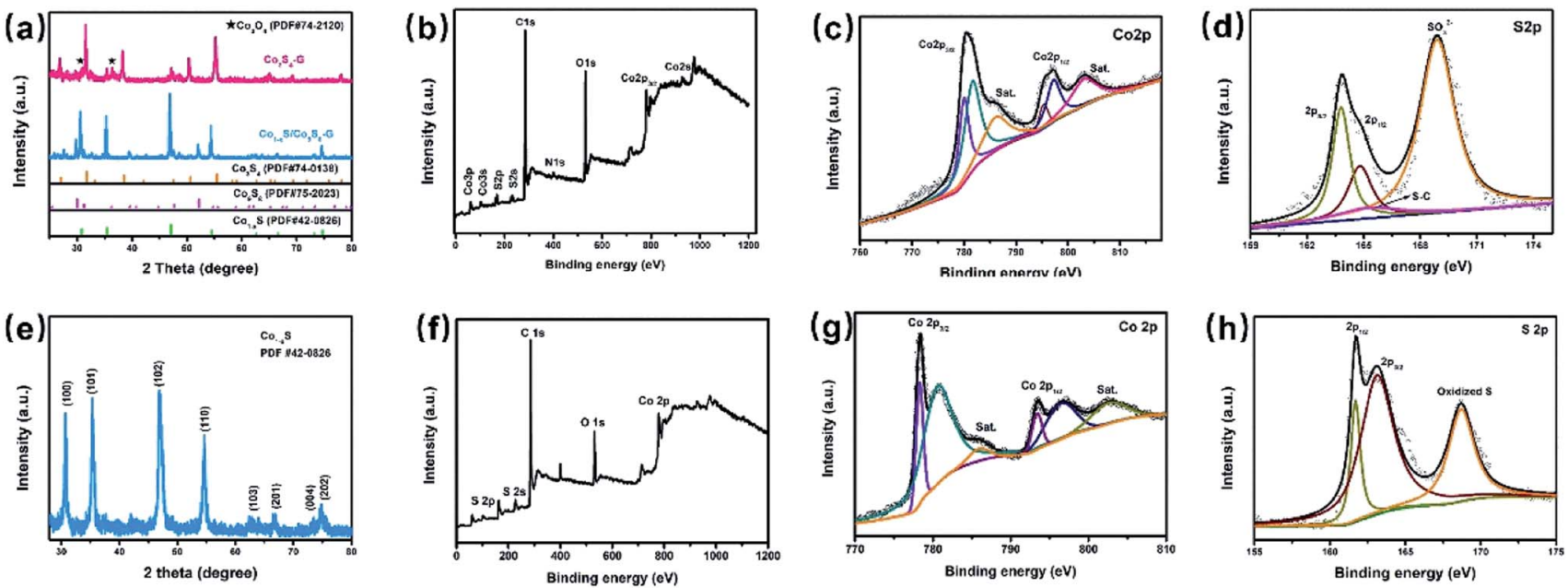

Fig. 1 (a) XRD patterns of $\mathrm{Co}_{1-x} \mathrm{~S} / \mathrm{Co}_{9} \mathrm{~S}_{8}-\mathrm{G}$ and $\mathrm{Co}_{3} \mathrm{~S}_{4}-\mathrm{G}$; (b) XPS spectrum of $\mathrm{Co}_{3} \mathrm{~S}_{4}-\mathrm{G}$; (c) Co 2p, (d) $\mathrm{S} 2 \mathrm{p}$, XPS spectra of Co $3 \mathrm{~S}_{4}-\mathrm{G}$; (e) XRD patterns of $\mathrm{CO}_{1-x} \mathrm{~S}-\mathrm{CNT}$; (f) XPS spectrum of $\mathrm{CO}_{1-x} \mathrm{~S}-\mathrm{CNT}$; (g) Co $2 \mathrm{p}$ (h) S 2p, XPS spectra of $\mathrm{CO}_{1-x} \mathrm{~S}-\mathrm{CNT}$. 

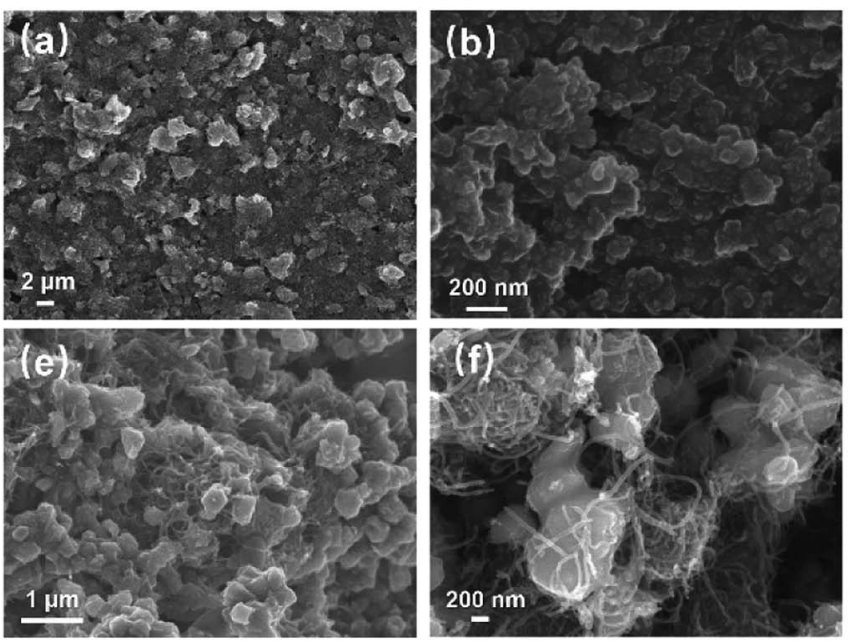
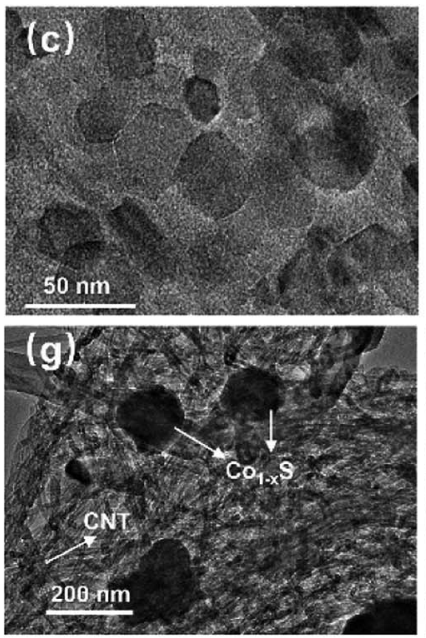

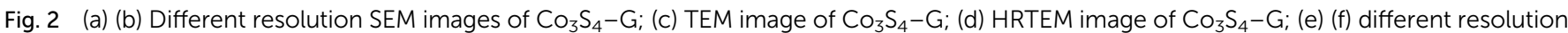
SEM images of $\mathrm{CO}_{1-x} \mathrm{~S}-\mathrm{CNT}$; (g) TEM image of $\mathrm{CO}_{1-x} \mathrm{~S}-\mathrm{CNT}$; (h) HRTEM image of $\mathrm{CO}_{1-x} \mathrm{~S}-\mathrm{CNT}$.

To investigate the electrochemical catalytic activity of these cobalt sulfides based materials, the GOR and ORR performances were studied by a series of tests (described in the
Experimental section). Fig. 3a shows the $\mathrm{CVs}$ of $\mathrm{Co}_{3} \mathrm{~S}_{4}-\mathrm{G}$ modified GCE $\left(\mathrm{Co}_{3} \mathrm{~S}_{4}-\mathrm{G} / \mathrm{GCE}\right)$ and bare GCE in $0.1 \mathrm{M} \mathrm{KOH}$ in the presence of $5 \mathrm{mM}$ glucose at a scan rate of $50 \mathrm{mV} \mathrm{s}^{-1}$. The (a)

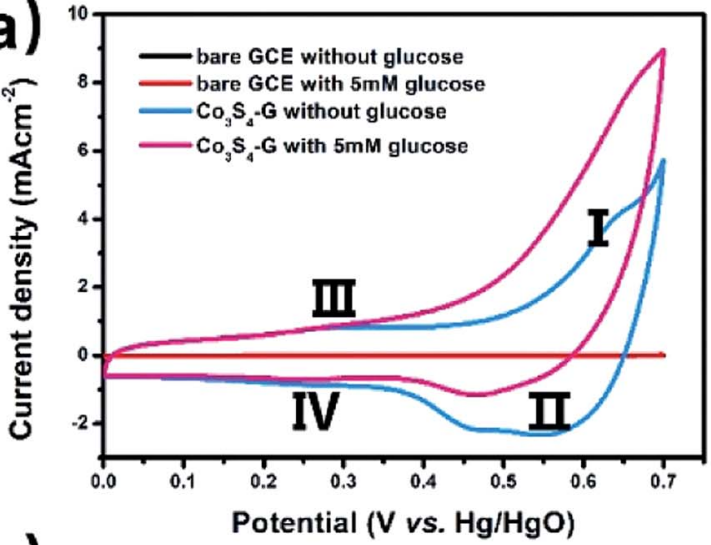

(c)

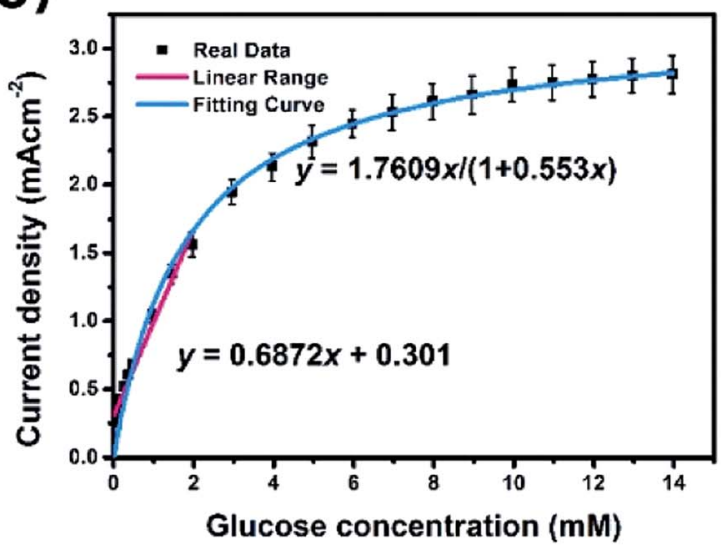

(b)

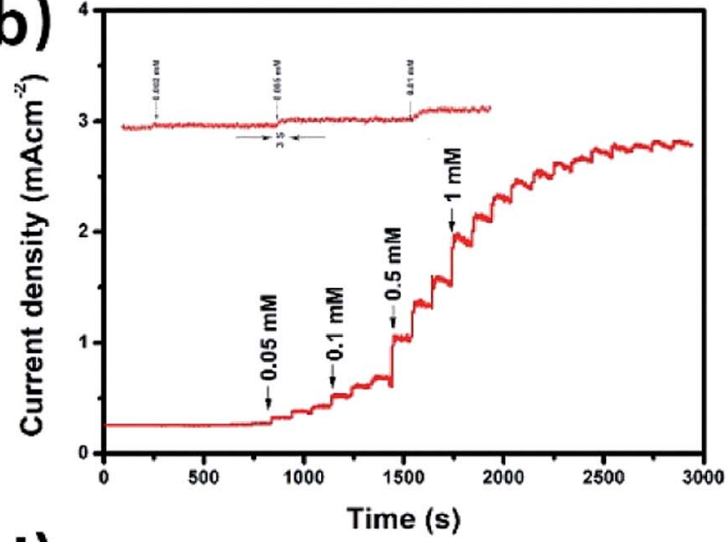

(d)

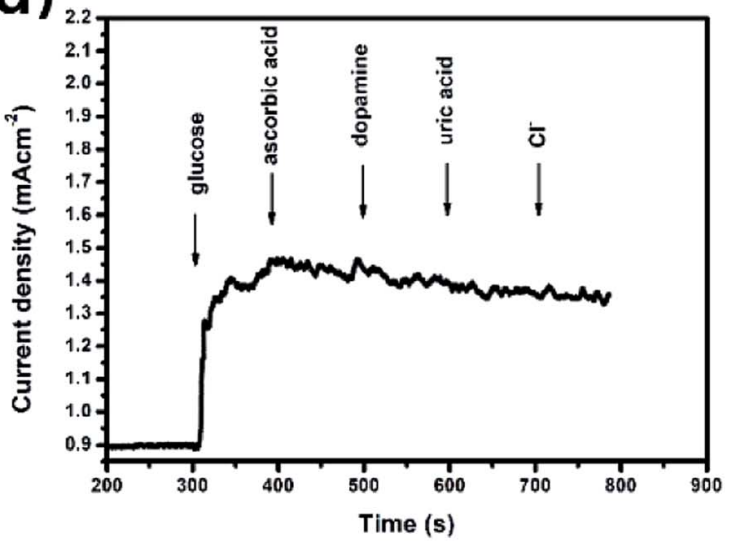

Fig. $3 \mathrm{CO}_{3} \mathrm{~S}_{4}-\mathrm{G}$ hybrid as glucose oxidation catalysts. (a) $\mathrm{CV}$ curves of bare $\mathrm{GCE}$ and $\mathrm{CO}_{3} \mathrm{~S}_{4}-\mathrm{G}$ in $0.1 \mathrm{M} \mathrm{KOH}$ with $5 \mathrm{mM}$ glucose or without glucose; (b) amperometric current response of a $\mathrm{Co}_{3} \mathrm{~S}_{4}-\mathrm{G}$ electrode in $0.1 \mathrm{M} \mathrm{KOH}$ with the continuous addition of glucose at $0.62 \mathrm{~V}$; (c) calibration curve versus glucose concentration; (d) amperometric current response of a $\mathrm{Co}_{3} \mathrm{~S}_{4}-\mathrm{G}$ electrode in $0.1 \mathrm{M}$ KOH with successive addition of glucose, ascorbic acid, dopamine, uric acid and $\mathrm{Cl}^{-}$. 
$\mathrm{Co}_{1-x} \mathrm{~S}-\mathrm{G}$ displays two pairs of redox peaks, anodic peaks at around $0.62 \mathrm{~V}$ and $0.28 \mathrm{~V}$, and cathodic peaks at around $0.55 \mathrm{~V}$ and $0.24 \mathrm{~V}$. The pair of redox peaks $\mathrm{I} / \mathrm{II}$ correspond to the reversible transition between $\mathrm{Co}^{3+}$ and $\mathrm{Co}^{4+}$, while peaks III/IV can be assigned to the conversion between $\mathrm{Co}^{2+}$ and $\mathrm{Co}^{3+} .^{40}$ Notably, an obvious increase of the anodic peak current was observed after the addition of glucose, especially at peak I. The electrooxidation process was mainly carried out by $\mathrm{Co}^{3+}$ and $\mathrm{Co}^{4+} \cdot \mathrm{Co}^{2+}$ was initially oxidized to $\mathrm{Co}^{3+}$ and further to $\mathrm{Co}^{4+}$. Then, the electrooxidation of glucose occured at the cost of $\mathrm{Co}^{4+}$ consumption, leading to an enhanced anodic current at peak I and a decrease in the cathodic peak current. The oxidation mechanism of $\mathrm{Co}_{3} \mathrm{~S}_{4}$ as an active substance can be shown by the following reactions: ${ }^{\mathbf{1 1}}$

$$
\begin{gathered}
\mathrm{Co}_{3} \mathrm{~S}_{4}+\mathrm{OH}^{-} \leftrightarrow \mathrm{Co}_{3} \mathrm{~S}_{4} \mathrm{OH}+\mathrm{e}^{-} \\
\mathrm{Co}_{3} \mathrm{~S}_{4} \mathrm{OH}+\mathrm{OH}^{-} \leftrightarrow \mathrm{Co}_{3} \mathrm{~S}_{4} \mathrm{O}+\mathrm{H}_{2} \mathrm{O}+\mathrm{e}^{-} \\
\mathrm{Co}^{4+}+\text { glucose } \rightarrow \mathrm{Co}^{3+}+\text { gluconolactone }
\end{gathered}
$$

The $\mathrm{Co}_{1-x} \mathrm{~S}-\mathrm{G}$ performance can clearly seen by the a evident catalytic current peak about $4.12 \mathrm{~mA} \mathrm{~cm} \mathrm{~cm}^{-2}$ in an intensity at $0.62 \mathrm{~V}$ ( $v s$. $\mathrm{Hg} / \mathrm{HgO}$ ) in the presence of glucose, compared with that $\mathrm{ub}$ the absence of glucose. In contrast, bare GCE exhibits a fairly weak response toward the oxidation of glucose. As shown in Fig. 3a, the current increase with the addition of glucose at peak I $\left(\mathrm{Co}^{3+} \rightarrow \mathrm{Co}^{4+}\right)$ was much stronger than that at peak III $\left(\mathrm{Co}^{2+} \rightarrow \mathrm{Co}^{3+}\right)$, which may suggest that the electrooxidation of glucose is mainly mediated by $\mathrm{Co}^{3+} / \mathrm{Co}^{4+}$, rather than $\mathrm{Co}^{2+} / \mathrm{Co}^{3+}$ in an alkaline solution. Therefore, the peak I potential $(+0.62 \mathrm{~V} v s$. $\mathrm{Hg} / \mathrm{HgO}$ ) was applied for the following amperometric detection. Fig. 3b shows the amperometric current response of $\mathrm{Co}_{3} \mathrm{~S}_{4}-\mathrm{G}$ in $0.1 \mathrm{M} \mathrm{KOH}$ with the continuous addition of glucose at $0.62 \mathrm{~V}$ ( $v s$. $\mathrm{Hg} / \mathrm{HgO}$ ). It had a fast amperometric response toward glucose and achieved steady state current density within $3 \mathrm{~s}$. However, the baseline exhibited slight drift after multiple additions of glucose, which can be attribute to faster consumption of glucose than the diffusion or the adsorption of intermediates on the active sites. ${ }^{\mathbf{4 2}}$ The fitting curve of this glucose sensor is shown in Fig. 3c. Langmuir isothermal theory was used to fit the curve, because the electrochemical oxidation of glucose on $\mathrm{Co}_{3} \mathrm{~S}_{4}-\mathrm{G}$ is a surface catalytic reaction. ${ }^{\mathbf{4 0}}$ From the Langmuir isothermal theory, the concentration of glucose adsorbed on the catalyst surface $\left(C_{\text {glu- }}\right.$ cose s) can be expressed as:

$$
C_{\text {glucose S }}=\frac{K_{\mathrm{A}} C_{\text {glucose }} C_{\mathrm{t}}}{1+K_{\mathrm{A}} C_{\text {glucose }}}
$$

where, $K_{\mathrm{A}}$ is the adsorption equilibrium constant, $C_{\mathrm{t}}$ it the total molar concentration of active sites on $\mathrm{Co}_{3} \mathrm{~S}_{4}-\mathrm{G}$ which is constant, and $C_{\text {glucose }}$ is the concentration of glucose in the bulk electrolyte. Therefore, at a given applied potential, the current density response $J$ from electrochemical oxidation of glucose is approximately proportional to $C_{\text {glucose }}$, with a rate constant of $K_{\mathrm{B}}$. Thus, $J$ can be expressed as follows by defining a new constant $K=K_{\mathrm{A}} K_{\mathrm{B}} C_{\mathrm{t}}$ :

$$
J=K_{\mathrm{B}} C_{\text {glucose S }}=\frac{K_{\mathrm{B}} K_{\mathrm{A}} C_{\text {glucose }} C_{\mathrm{t}}}{1+K_{\mathrm{A}} C_{\text {glucose }}}=\frac{K C_{\text {glucose }}}{1+K_{\mathrm{A}} C_{\text {glucose }}}
$$

As shown in Fig. 3c, the $K=1.7609$ and $K_{\mathrm{A}}=0.553$ of this equation can be calculated with a sufficient fitness $(R=0.985)$. Thus $J$ can be expressed as follows:

$$
J=\frac{1.76084 C_{\text {glucose }}}{1+0.55296 C_{\text {glucose }}}
$$

At lower glucose concentrations, it exhibited a linear range from 0 to $2 \mathrm{mM}$, a sensitivity of $687.2 \mu \mathrm{A} \mathrm{cm}{ }^{-2} \mathrm{mM}^{-1}$ and a detection limit of $0.4 \mu \mathrm{M}(\mathrm{S} / \mathrm{N}=3)$ was achieved. These glucose oxidation results are superior to most of the reported electrochemical glucose sensors. The stability of $\mathrm{Co}_{3} \mathrm{~S}_{4}-\mathrm{G}$ electrode was investigated by measuring its amperometric response for a long operational period. Fig. S5a $\uparrow$ displays the amperometric response to $0.1 \mathrm{mM}$ glucose within a 7 day period. After 7 days, the final amperometric response was approximately $97 \%$ of its original counterpart. As shown in Fig. S5b, $\uparrow$ there is nearly no loss in the current signal over a period of $3500 \mathrm{~s}$ for $0.1 \mathrm{mM}$ glucose in $0.1 \mathrm{M} \mathrm{KOH}$ at $+0.62 \mathrm{~V}$, suggesting excellent stability of the $\mathrm{Co}_{3} \mathrm{~S}_{4}-\mathrm{G}$ electrode. Selectivity performance of $\mathrm{Co}_{3} \mathrm{~S}_{4}-\mathrm{G}$ is shown in Fig. 3d. With the successive of addition of glucose and other interferences in $0.1 \mathrm{M} \mathrm{KOH}$, it can be seen that $\mathrm{Co}_{3} \mathrm{~S}_{4}-\mathrm{G}$ has a remarkable response for glucose, superior to that of the interfering species. All the above results show that $\mathrm{Co}_{3} \mathrm{~S}_{4}-\mathrm{G}$ is an excellent glucose electrochemical catalyst. According to the test above, the $\mathrm{Co}_{3} \mathrm{~S}_{4}-\mathrm{G}$ hybrid can be considered as a high performance glucose catalyst.

The ORR activities of $\mathrm{Co}_{1-x} \mathrm{~S}-\mathrm{CNT}$ were evaluated by rotating disk electrode (RDE) measurements in $0.1 \mathrm{M} \mathrm{KOH}$ solution. Fig. 4a shows the linear scan sweep voltammetry (LSV) curves of $\mathrm{Co}_{1-x} \mathrm{~S}-\mathrm{CNT}$, commercial Pt/C, $\mathrm{Co}_{1-x} \mathrm{~S}$ and CNTs at $1600 \mathrm{rpm}$, $\mathrm{Co}_{1-x} \mathrm{~S}-\mathrm{CNT}$ exhibited an onset potential of $0.01 \mathrm{~V}(v s . \mathrm{Hg} / \mathrm{HgO})$, which was close to that of the commercial Pt/C $(0.025 \mathrm{~V})$. $\mathrm{Co}_{1-x} \mathrm{~S}-\mathrm{CNT}$ showed a large positive shift in the half wave potentials of $\mathrm{Co}_{1-x} \mathrm{~S}, \mathrm{CNTs}$ and commercial Pt/C attribute to the synergistic effect of $\mathrm{Co}_{1-x} \mathrm{~S}$ and CNT. The $\mathrm{Co}_{1-x} \mathrm{~S}-\mathrm{CNT}$ had a limiting current density of $5.15 \mathrm{~mA} \mathrm{~cm}^{-2}$ at $-0.8 \mathrm{~V}$. However, this activity is still lower than that of $\mathrm{Pt} / \mathrm{C}\left(5.7 \mathrm{~mA} \mathrm{~cm}{ }^{-2}\right)$. To quantitatively measure the ORR catalytic pathway of the $\mathrm{Co}_{1-x} \mathrm{~S}-\mathrm{CNT}$ hybrid, the RRDE test was used to monitor the formation of peroxide species $\left(\mathrm{HO}_{2}{ }^{-}\right)$during the ORR process (Fig. 4b). Fig. 4c shows the measured $\mathrm{HO}_{2}{ }^{-}$yield was below $9 \%$ for $\mathrm{Co}_{1-x} \mathrm{~S}-\mathrm{CNT}$ and the corresponding electron transfer number $(n)$ was above 3.85 over the potential range of $-0.8 \mathrm{~V}$ to $-0.2 \mathrm{~V}$, suggesting that the $\mathrm{Co}_{1-x} \mathrm{~S}-\mathrm{CNT}$ catalyst exhibits a dominant four-electron oxygen reduction process. Furthermore, after $30000 \mathrm{~s}$ of long-term measurements of continuous ORR at $-0.5 \mathrm{~V}$ in an $\mathrm{O}_{2}$-saturated $0.1 \mathrm{M} \mathrm{KOH}$ at $900 \mathrm{rpm}$, the current density remained at about $85 \%$ of the $\mathrm{Co}_{1-x} \mathrm{~S}-\mathrm{CNT}$ hybrid, whereas the attenuation for $\mathrm{Pt} / \mathrm{C}$ was up to $31 \%$. Considering the above analysis of the ORR activity test results, 
(a)

(c) $\mathrm{KOH}$ at $900 \mathrm{rpm}$.
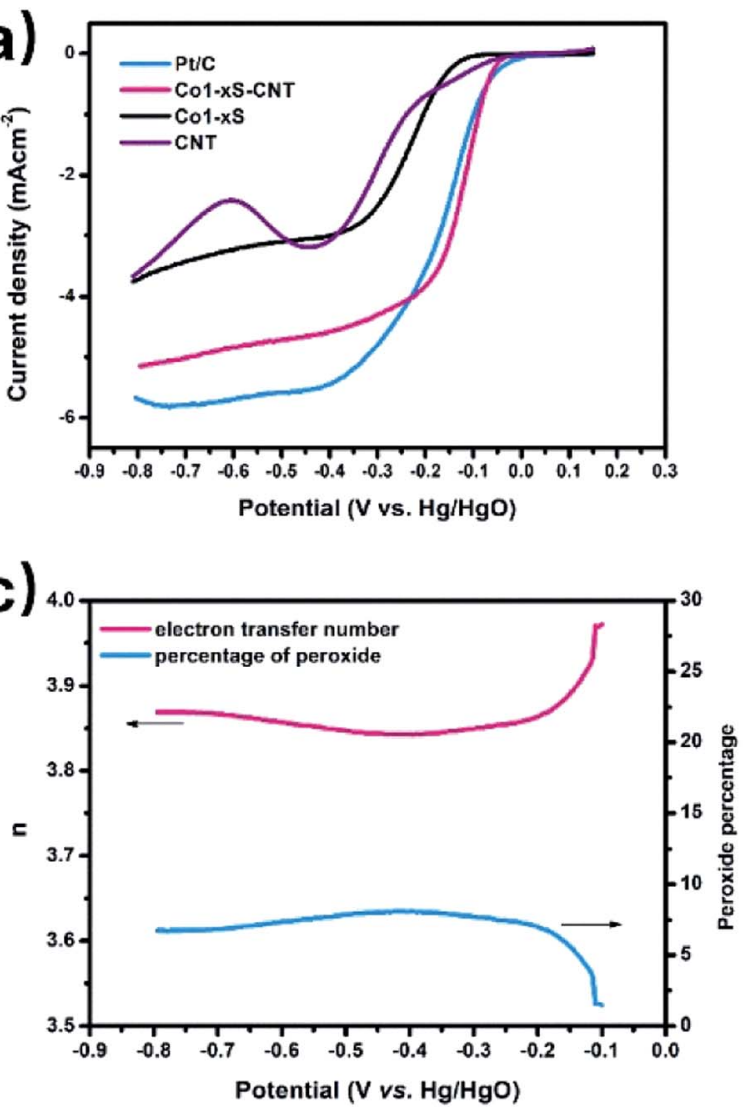

(b)

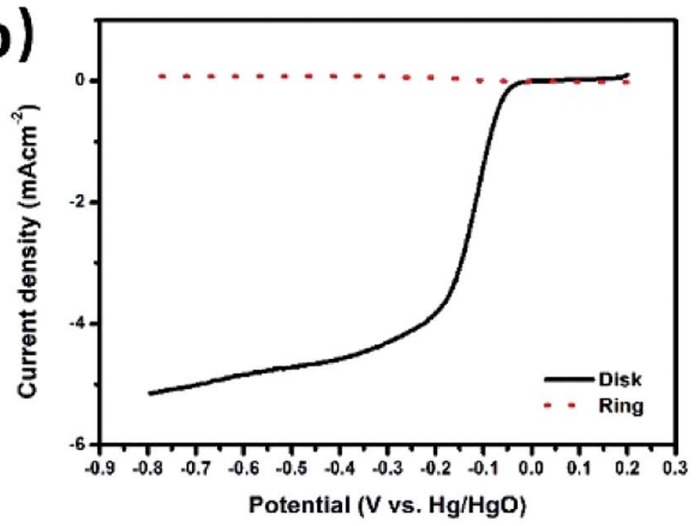

(d)

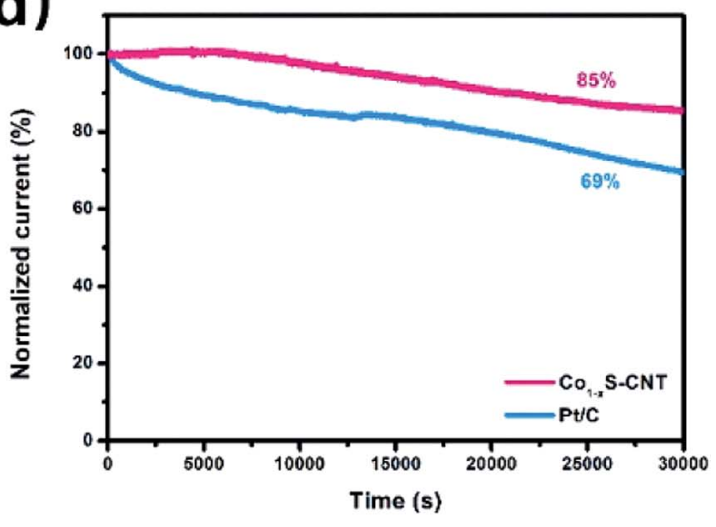

Fig. $4 \mathrm{Co}_{1-x} \mathrm{~S}-\mathrm{CNT}$ hybrid as oxygen reduction catalysts. (a) LSV curves of commercial Pt/C, $\mathrm{CO}_{1-x} \mathrm{~S}-\mathrm{CNT}_{1} \mathrm{CO}_{1-x} \mathrm{~S}$ and $\mathrm{CNTS}$ in $\mathrm{O}_{2}-\mathrm{saturated}$ $0.1 \mathrm{M} \mathrm{KOH}$ at a sweep rate of $5 \mathrm{mV} \mathrm{s}^{-1}$; (b) RRDE experiment results of $\mathrm{CO}_{1-x} \mathrm{~S}-\mathrm{CNT}$ electrode for ORR in $0.1 \mathrm{M} \mathrm{KOH}$ at a scan rate of $5 \mathrm{mV} \mathrm{s}{ }^{-1}$; (c) corresponding percentage of peroxide in the total oxygen reduction products and the electron transfer number ( $n$ ) calculated by the RRDE result; (d) chronoamperometric stability tests of the commercial Pt/C and $\mathrm{Co}_{1-x} \mathrm{~S}-\mathrm{CNT}$ for $30000 \mathrm{~s}$ at $-0.5 \mathrm{~V}(\mathrm{vs}$. $\mathrm{Hg} / \mathrm{HgO})$ in $\mathrm{O}_{2}-\mathrm{saturated} 0.1 \mathrm{M}$

the $\mathrm{Co}_{1-x} \mathrm{~S}-\mathrm{CNT}$ hybrid had a high catalytic ORR activity and stability catalyst.

The H-type glucose fuel cell was fabricated using the $\mathrm{Co}_{3} \mathrm{~S}_{4}-\mathrm{G}$ hybrid as the anode and the $\mathrm{Co}_{1-x} \mathrm{~S}-\mathrm{CNT}$ as the cathode catalyst. Fig. 5 shows the schematic of the H-type glucose fuel cell. Glucose was oxidized by $\mathrm{Co}_{3} \mathrm{~S}_{4}-\mathrm{G}$ at the anode, and the electrons and protons generated by the glucose oxidation reaction were transferred from the anode

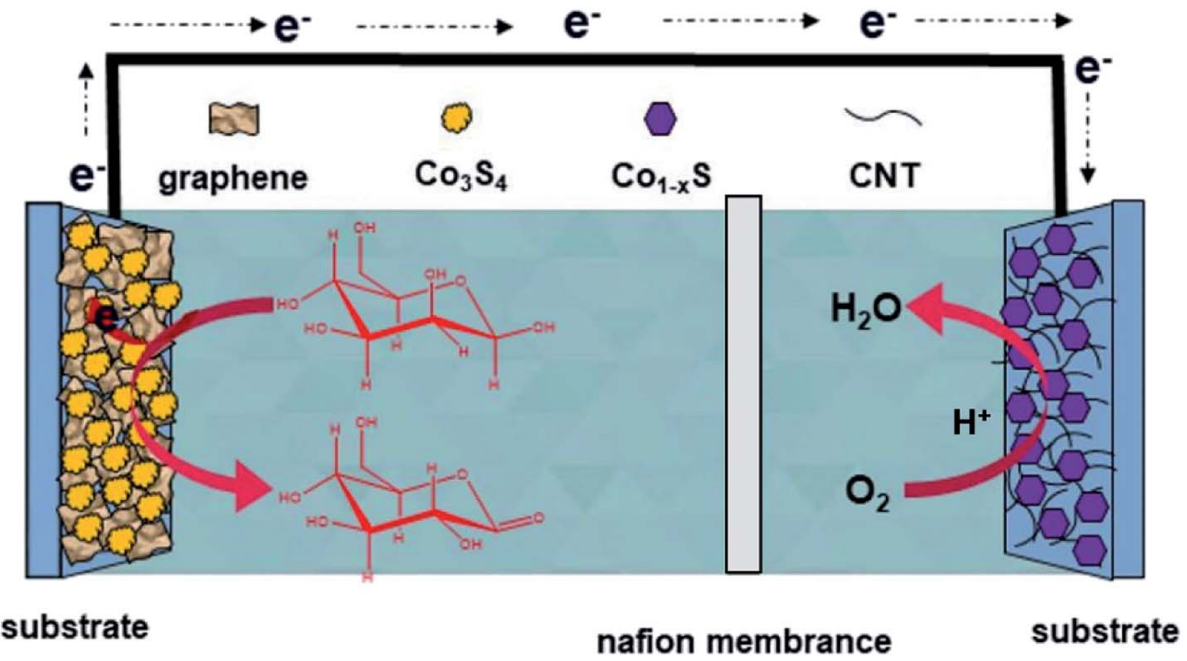

Fig. 5 Schematic and working mechanism of the designed glucose fuel cell. 
(a)

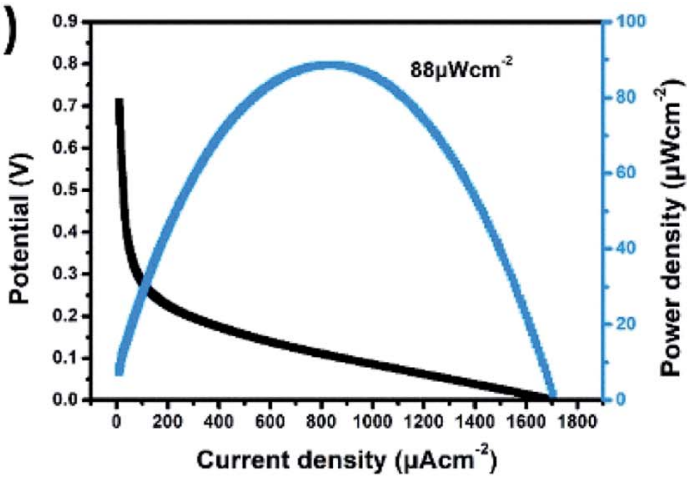

(b)

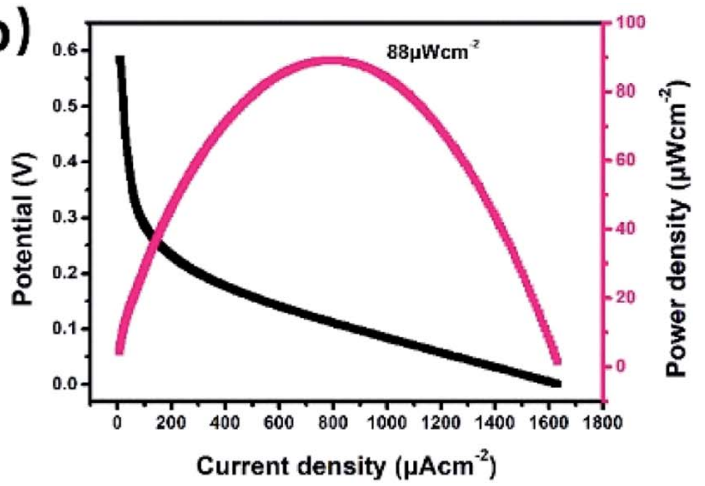

(c)

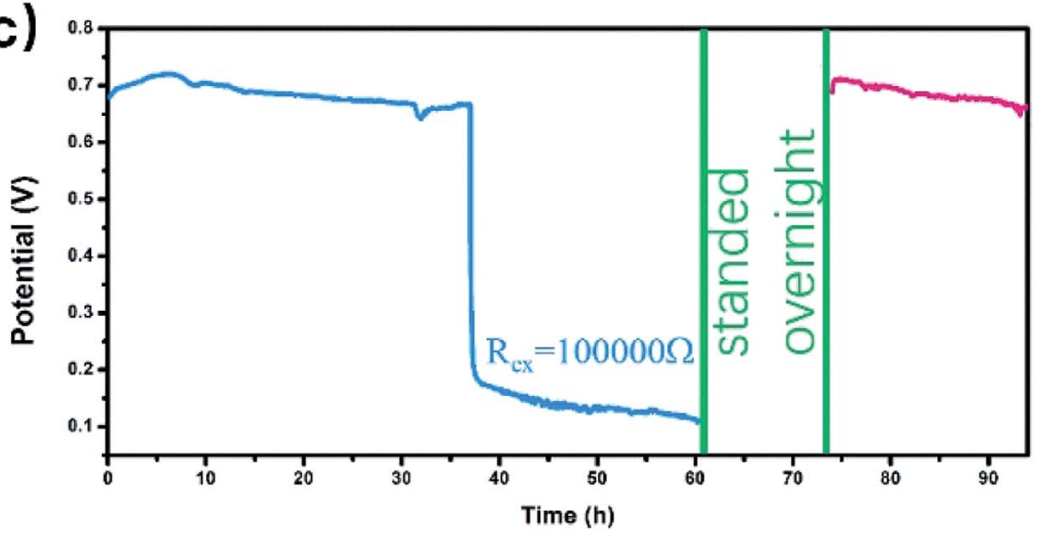

Fig. $6 \mathrm{H}$-type glucose fuel cell tests. (a) Polarization and power density curves of the $\mathrm{Co}_{3} \mathrm{~S}_{4}-\mathrm{G} / \mathrm{Co}_{1-x} \mathrm{~S}-\mathrm{CNT}_{(\mathrm{allc})}$-GFC; (b) power density and current density measured with long-time placed $\mathrm{CO}_{3} \mathrm{~S}_{4}-\mathrm{G}$ as the anode and long-time placed $\mathrm{CO}_{1-x} \mathrm{~S}-\mathrm{CNT}$ as the cathode; (c) output potential recorded for the $\mathrm{Co}_{3} \mathrm{~S}_{4}-\mathrm{G} / \mathrm{CO}_{1-x} \mathrm{~S}-\mathrm{CNT}_{(\mathrm{a} \| \mathrm{c})}-\mathrm{GFC}$.

to the cathode through an external circuit and internal solution, respectively. At the cathode, $\mathrm{O}_{2}$ was reducted to $\mathrm{H}_{2} \mathrm{O}$ by the action of $\mathrm{Co}_{1-x} \mathrm{~S}-\mathrm{CNT}$. As shown in Fig. $6 \mathrm{a}$, the open circuit voltage (OCV) was $0.72 \mathrm{~V}$, the maximum current density was $\sim 1700 \mu \mathrm{A} \mathrm{cm} \mathrm{cm}^{-2}$, and the maximum power density was $88 \mu \mathrm{W} \mathrm{cm} \mathrm{cm}^{-2}$. It had the same maximum power density, and a higher maximum current density $(\sim 650 \mu \mathrm{A}$ $\mathrm{cm}^{-2}$ ), compared with $\mathrm{Pt} / \mathrm{C}$ as the cathode catalyst (Fig. S6a†). A bare electrode fabricated glucose fuel cell is shown in Fig. S6b, $\uparrow$ which exhibited a poor maximum current density $\left(\sim 4.2 \mu \mathrm{A} \mathrm{cm}^{-2}\right)$ and maximum power density $\left(0.5 \mu \mathrm{W} \mathrm{cm}{ }^{-2}\right)$, proving that the excellent performance of the battery can be attributed to our catalyst $\left(\mathrm{Co}_{3} \mathrm{~S}_{4}-\mathrm{G}\right.$ and $\mathrm{Co}_{1-x} \mathrm{~S}-\mathrm{CNT}$ ). Meanwhile, the stability was a major factor to assess the performance of the fuel cell. We used electrodes that were placed for a long time after modification (in the air for one week) to fabricate the glucose fuel cell. As shown in Fig. $6 \mathrm{~b}$, it exhibited the same power density output $(88 \mu \mathrm{W}$ $\mathrm{cm}^{-2}$ ), proving that it was a stable catalyst. And long time discharge test was measured by land (CT2001A). As shown in Fig. $6 \mathrm{c}$, the potential had a loss of $7 \%$ within the initial $36 \mathrm{~h}$. Then loading an $R_{\mathrm{ex}}$ of $100 \mathrm{k} \Omega$, the voltage droped to $0.5 \mathrm{~V}$ and then stabilized at $\sim 0.2 \mathrm{~V}$ for $24 \mathrm{~h}$. Subsequently, the battery stood overnight at room temperature, and its voltage recovered to $\sim 0.7 \mathrm{~V}$ without external resistance. After $20 \mathrm{~h}$, it held a voltage of $\sim 0.66 \mathrm{~V}$. The generated voltage gradually decreased, which can be attributed to the glucose oxidizing to gluconolactone. ${ }^{15,43}$

\section{Conclusions}

We successfully synthesized cobalt sulfides/carbon nanohybrids and used them in NGBCs. The $\mathrm{Co}_{3} \mathrm{~S}_{4}-\mathrm{G}$ hybrid showed an excellent glucose electrooxidation activity, high sensitivity $\left(687.2 \mu \mathrm{A} \mathrm{cm} \mathrm{cm}^{-2} \mathrm{mM}^{-1}\right)$, low detection limit $(0.4$ $\mu \mathrm{M})$, fast response, and good selectivity toward the detection of glucose, which can be used as an anodic catalyst for glucose biofuel cells. Meanwhile, the $\mathrm{Co}_{1-x} \mathrm{~S}-\mathrm{CNT}$ hybrid exhibited surprisingly high ORR activities, comparable to commercial $\mathrm{Pt} / \mathrm{C}$ catalysts, and exceeded the stability of Pt/C. Therefore, $\mathrm{Co}_{1-x} \mathrm{~S}-\mathrm{CNT}$ can be used as a cathode catalyst for glucose biofuel cells. The as-designed glucose biofuel cell with $\mathrm{Co}_{3} \mathrm{~S}_{4}-$ $\mathrm{G}$ as the anode catalyst and $\mathrm{Co}_{1-x} \mathrm{~S}-\mathrm{CNT}$ as the cathode catalyst had advantages of being low cost, was free of enzymes, had a high open circuit voltage of $0.72 \mathrm{~V}$, a maximum open power density of $88 \mu \mathrm{W} \mathrm{cm}{ }^{-2}$, a maximum current density was $\sim 1700 \mu \mathrm{A} \mathrm{cm}{ }^{-2}$ and long-term stability. The voltage even stabilized at $\sim 0.2 \mathrm{~V}$ for $24 \mathrm{~h}$ with loading an $R_{\text {ex }}$ of $100 \mathrm{k} \Omega$, and its voltage can recover to $\sim 0.7 \mathrm{~V}$ without external resistance. Our findings provide a new direction for the rational design or modification of dual electrode catalysts of NBGCs. 


\section{Conflicts of interest}

There are no conflicts to declare.

\section{Acknowledgements}

The work is supported by the National Natural Science Foundation of China $(81301345,81871506)$.

\section{References}

1 K. L. Jiao, Y. Jiang, Z. P. Kang, R. Y. Peng, S. Q. Jiao and Z. Q. Hu, R. Soc. Open Sci., 2017, 4, 10.

2 Z. P. Kang, K. L. Jiao, J. Cheng, R. Y. Peng, S. Q. Jiao and Z. Q. Hu, Biosens. Bioelectron., 2018, 101, 60-65.

3 G. Y. Li, Z. H. Li, X. Xiao, Y. L. An, W. Wang and Z. Q. Hu, J. Mater. Chem. A, 2019, 7, 11077-11085.

4 I. Willner, Y. M. Yan, B. Willner and R. Tel-Vered, Fuel Cells, 2009, 9, 7-24.

5 Y. X. Chen, W. H. Ji, K. Yan, J. Gao and J. D. Zhang, Nano Energy, 2019, 61, 173-193.

6 Z. P. Kang, Y. Zhang and Z. G. Zhu, Biosens. Bioelectron., 2019, 132, 76-83.

7 L. Y. Fu, J. J. Liu, Z. Q. Hu and M. Zhou, Electroanalysis, 2018, 30, 2535-2550.

8 K. MacVittie, T. Conlon and E. Katz, Bioelectrochemistry, 2015, 106, 28-33.

9 A. Szczupak, J. Halamek, L. Halamkova, V. Bocharova, L. Alfonta and E. Katz, Energy Environ. Sci., 2012, 5, 88918895.

10 L. Halamkova, J. Halamek, V. Bocharova, A. Szczupak, L. Alfonta and E. Katz, J. Am. Chem. Soc., 2012, 134, 50405043.

11 J. A. Castorena-Gonzalez, C. Foote, K. MacVittie, J. Halamek, L. Halamkova, L. A. Martinez-Lemus and E. Katz, Electroanalysis, 2013, 25, 1579-1584.

12 A. Zebda, S. Cosnier, J. P. Alcaraz, M. Holzinger, A. Le Goff, C. Gondran, F. Boucher, F. Giroud, K. Gorgy, H. Lamraoui and P. Cinquin, Sci. Rep., 2013, 3, 5.

13 M. Chu, Y. J. Zhang, L. Yang, Y. M. Tan, W. F. Deng, M. Ma, X. L. Su, Q. J. Xie and S. Z. Yao, Energy Environ. Sci., 2013, 6, 3600-3604.

14 Y. Zhao, L. Z. Fan, D. M. Gao, J. L. Ren and B. Hong, Electrochim. Acta, 2014, 145, 159-169.

15 S. Ci, Z. Wen, S. Mao, Y. Hou, S. Cui, Z. He and J. Chen, Chem. Commun., 2015, 51, 9354-9357.

16 G. Slaughter and T. Kulkarni, Microelectron. Eng., 2016, 149, 92-96.

17 K. L. Jiao, Z. P. Kang, B. Wang, S. Q. Jiao, Y. Jiang and Z. Q. Hu, Electroanalysis, 2018, 30, 525-532.

18 S. Kerzenmacher, U. Kraling, T. Metz, R. Zengerle and F. von Stetten, J. Power Sources, 2011, 196, 1264-1272.
19 Y. Hou, Z. H. Wen, S. M. Cui, S. Q. Ci, S. Mao and J. H. Chen, Adv. Funct. Mater., 2015, 25, 872-882.

20 P. Y. Ren, S. Q. Ci, Y. C. Ding and Z. H. Wen, Appl. Surf. Sci., 2019, 481, 1206-1212.

21 D. H. Ge, H. B. Geng, J. Q. Wang, J. W. Zheng, Y. Pan, X. Q. Cao and H. W. Gu, Nanoscale, 2014, 6, 9689-9694.

22 M. Li, C. Han, Y. F. Zhang, X. J. Bo and L. P. Guo, Anal. Chim. Acta, 2015, 861, 25-35.

23 H. M. Xu, S. Q. Ci, Y. C. Ding, G. X. Wang and Z. H. Wen, J. Mater. Chem. A, 2019, 7, 8006-8029.

24 S. Gao, Y. Lin, X. C. Jiao, Y. F. Sun, Q. Q. Luo, W. H. Zhang, D. Q. Li, J. L. Yang and Y. Xie, Nature, 2016, 529, 68.

25 C. D. Bai, S. S. Wei, D. R. Deng, X. D. Lin, M. S. Zheng and Q. F. Dong, J. Mater. Chem. A, 2017, 5, 9533-9536.

26 Y. H. Wang, B. H. Wu, X. Y. He, Y. Y. Zhang, H. Li, Y. Y. Peng, J. Wang and J. B. Zhao, Electrochim. Acta, 2017, 230, 299-307.

27 X. Qiao, J. Jin, H. Fan, Y. Li and S. Liao, J. Mater. Chem. A, 2017, 5, 12354-12360.

28 H. L. Wang, Y. Y. Liang, Y. G. Li and H. J. Dai, Angew. Chem., Int. Ed., 2011, 50, 10969-10972.

29 X. R. Li, J. L. Wei, Q. Li, S. S. Zheng, Y. X. Xu, P. Du, C. Y. Chen, J. Y. Zhao, H. G. Xue, Q. Xu and H. Pang, Adv. Funct. Mater., 2018, 28, 7.

30 B. Li, Y. X. Shi, K. S. Huang, M. M. Zhao, J. Q. Qiu, H. G. Xue and H. Pang, Small, 2018, 14, 7.

31 J. L. Guan, Z. P. Zhang, J. Ji, M. L. Dou and F. Wang, ACS Appl. Mater. Interfaces, 2017, 9, 30662-30669.

32 L. Tan, S. J. Li, X. T. Wu, N. Li and Z. Q. Liu, Int. J. Hydrogen Energy, 2018, 43, 10311-10321.

33 X. R. Li, S. Y. Ding, X. Xiao, J. Y. Shao, J. L. Wei, H. Pang and Y. Yu, J. Mater. Chem. A, 2017, 5, 12774-12781.

34 F. Luo, D. T. Ma, Y. L. Li, H. W. Mi, P. X. Zhang and S. Luo, Electrochim. Acta, 2019, 299, 173-181.

35 X. Wang, C. Liu, Q. Li, H. Li, J. Xu, X. Chu, L. Zhang, G. Zhao, H. Li, P. Guo, S. Li and X. S. Zhao, ChemElectroChem, 2018, 5, 309-315.

36 B. Liu, D. Kong, J. Zhang, Y. Wang, T. Chen, C. Cheng and H. Y. Yang, J. Mater. Chem. A, 2016, 4, 3287-3296.

37 D. He, X. Wu, W. Liu, C. Lei, C. Yu, G. Zheng, J. Pan, L. Lei and X. Zhang, Chin. Chem. Lett., 2019, 30, 229-233.

38 M. Chauhan, K. P. Reddy, C. S. Gopinath and S. Deka, ACS Catal., 2017, 7, 5871-5879.

39 X. Li, C. Hao, B. Tang, Y. Wang, M. Liu, Y. Wang, Y. Zhu, C. Lu and Z. Tang, Nanoscale, 2017, 9, 2178-2187.

40 Y. Ding, Y. Wang, L. A. Su, M. Bellagamba, H. Zhang and Y. Lei, Biosens. Bioelectron., 2010, 26, 542-548.

41 A. L. Meng, L. Y. Sheng, K. Zhao and Z. J. Li, J. Mater. Chem. $B, 2017, \mathbf{5}, 8934-8943$.

42 Y. W. Liu, X. Q. Cao, R. M. Kong, G. Du, A. M. Asiri, Q. Lu and X. P. Sun, J. Mater. Chem. B, 2017, 5, 1901-1904.

43 E. H. Zhang, Y. Xie, S. Q. Ci, J. C. Jia and Z. H. Wen, Biosens. Bioelectron., 2016, 81, 46-53. 